\title{
Gendered positionality among Irish male primary teachers: the staff room as a site of performative masculinity
}

\section{Suzanne O'Keeffe \& Jim Deegan}

To cite this article: Suzanne O'Keeffe \& Jim Deegan (2018) Gendered positionality among Irish male primary teachers: the staff room as a site of performative masculinity, Irish Educational Studies, 37:3, 373-389, DOI: 10.1080/03323315.2018.1484301

To link to this article: https://doi.org/10.1080/03323315.2018.1484301

曲 Published online: 19 Jun 2018.

Submit your article to this journal $\pi$

Lلll Article views: 130

View Crossmark data $\complement$ 


\title{
Gendered positionality among Irish male primary teachers: the staff room as a site of performative masculinity
}

\author{
Suzanne O'Keeffe (1) a* and Jim Deegan ${ }^{\mathrm{b}}$ \\ ${ }^{a}$ Department of Reflective Pedagogy and Early Childhood Studies, Mary Immaculate College, \\ Limerick, Ireland; ${ }^{b}$ Research and Graduate School, Mary Immaculate College, Limerick, Ireland
}

(Received 14 June 2017; accepted 3 May 2018)

\begin{abstract}
The concept of masculinities has traditionally been defined in terms of crises associated with boys' underachievement, the violence of homophobia, the underrepresentation of males in caring occupations, the rituals and discourses of laddism, and perceptions of disaffected and unrealised talent. Whereas the topic of masculinities has long been associated with warrants for distinctive and diverse male identities, it has a comparatively more recent history in the research on male Irish primary teachers as a particular social category. Two key findings are discussed in relation to performative masculinities - a form of strategic manoeuvring designed to exploit gender discourses, practices for control, power and privilege. First, the findings show the staffroom as a bellwether or highly developed locus for teacher socialisation through gendered discourses, events and actions. Second, the findings show nonsynchronous performative masculinities not only between male and female teachers but also with male colleagues. Therefore, it is argued that this frequently forgotten and neglected seam in the grand narrative of schools and schooling in Ireland needs to be more fully understood as a variable of quality, social justice and democratic practices across the full scope and sequence of the teacher continuum and as a prerequisite component in all teacher leadership programmes.
\end{abstract}

Keywords: gender; feminist research; hegemonic masculinities; primary education

\section{Introduction}

The ways in which we understand masculinities and embed these understandings as everyday realities have undergone profound changes in recent decades in the Republic of Ireland (Holohan and Tracy 2014). Against a backcloth of heritage, popular and cinematic perspectives, the Irish male has been variously described with laughter and tears as 'a mixture of flaming ego, hot temper, stubbornness, great personal charm and warmth, and a wit that shines through adversity ... an irrepressible buoyancy, a vivacious spirit, a kindliness and tolerance for the common frailties...' (Mowbray 1997, 1). A more complex, reflexive, nuanced and hyphenated understanding of the Irish male is emergent in the second decade of the twenty-first century. Today, variables of race, ethnicity, gender, class, sexuality, belief and ability, among other variables of social analysis (Holohan and Tracy 2014), are prerequisite considerations in sociological discourses on Irish male identities. This paper focuses on the

\footnotetext{
*Corresponding author. Email: suzanne.okeeffe@mic.ul.ie 
largely forgotten and neglected seam of the sociological construct of gendered positionality - a form of strategic manoeuvring designed to exploit gender discourses, behaviours and bodily matters for power, privilege and control - among male primary teachers in selected staffrooms in the Republic of Ireland.

This paper begins by providing an aspect on contemporary debates and controversies about gender, schools and schooling. Next, recent statutory and policy discourses with reference to gender diversities are discussed. Then, gendered positionality through the theoretical lens of postmodern and post-structuralists with a focus on sample, contexts and settings and the long interview as a research method is discussed. Analysis includes discussion of hegemonic masculinities and themes related to the politics of male subordination, marginalisation, nonsynchronous identities and the body as a site of performative power and control. This paper concludes with a discussion of the potential and possibilities of research with male teachers who do not align themselves with dominant and hegemonic masculinities.

\section{Contemporary debates and controversies about gender, schools and schooling}

Support for denominational and parochial education (Tuohy 2013) and the overhaul of pluralism and patronage in denominational schools is one example of the divergences, polarisations and contestations currently taking place in schools and schooling in the Republic of Ireland. These contestations are evident in the play of traditional values and beliefs, on the one hand (Coolahan, Hussey, and Kilfeather 2012), and the logics of populational reasoning, on the other (Popkewitz and Lindblad 2000). Another contested site is the vexed issue of teacher supply and demand, which is fraught with challenges and conflicts in relation to primary principal recruitment (IPPN 2006) and teacher substitution shortages (INTO 2016a). This particular issue has been seriously exacerbated by a tripartite pay scale regime for primary teachers. One particularly egregious tension is that pay scales in recent years have been predicated on human resource variables and, more specifically, tied to a teacher's first date of appointment to a teaching position (Eurydice 2015, 12). Long-standing reward schemes or allowances for qualification awards, geographical variance and teaching in the Irish language were withdrawn for primary teachers appointed to a teaching position for the first time from 1 February 2012 (Eurydice 2015, 24). A compounding resource variable is that primary teachers teach larger classes than their European counterparts, or a ratio of 1:16 according to the Department of Education and Science (DES 2016, 18) with four more pupils on average per class (INTO 2016b, 11). The pervasiveness of neo-liberal technocracies (Popkewitz and Lindblad 2000) and emphasis on measured and measurable variables of analysis have resulted in an enveloping and enfolding audit culture. Turning more specifically to gender as a variable of social analysis, 'accountability, measurement and management' (Apple 2013, 128) have important implications for performative and public masculinities in the primary schools.

\section{Renaissance masculinities}

Increased public awareness about gendered positioning has altered historical conceptions of masculinities, shifting understandings of masculinities from those that have been knowable to those that are partially unknowable (Haywood and Mac an 
Ghaill 2013). Traditional occupational styles and loci have ensured that workplace performances, until quite recently, were key resources in the self-production of male identity. In counterpoint to traditional and somewhat calcified notions of the principal teacher in the local parish school as 'the master', contemporary work conditions blur the boundaries between conventional masculine and feminine ascribed traits such as " ... the changing nature of work [which] requires the cultivation of an elite masculinity that is more sensitive and reflexive ...' (Haywood and Mac an Ghaill 2013, 67). This supposed cosmopolitan masculinity or 'Renaissance' masculinity (Skelton and Francis 2009) suggests a move away from the values associated with traditional conservative masculinity such as emotional indifference toward the 'feminine traits' of empathy, patience and understanding. The adoption of feminine values is in response to neoliberal market competition, which implies that feminine skills and attitudes better meet the changing requirements of global capitalism (Haywood and Mac an Ghaill 2013). In recognising the changing nature of work, this paper brings forward a discussion of male teachers' emotions, feelings and desires as 'projects of choice and the emotional self' (Lupton 1998) in counterpoint to essentialist manoeuvres designed to promote privilege and foster power.

\section{Valuing values}

Gendered positionality plays a key role in the primary school as an intact organisational and cultural unit, albeit as Hargreaves (2010) writes characterised by 'presentism, individualism, and conservatism' (143). This is a unit of analysis where teachers are workers and like all workers are expected to navigate the 'emotional geographies of [teachers'] relations with their colleagues' (Hargreaves 2001, 503) and manage feelings of love, care and compassion inscribed in organisationally defined rules and guidelines. The primary school as a locus of identity formation and meaning-making is key to knowing 'what is happening with individuals in their working lives' and for identifying 'how people encounter encouragement, scepticism, support and suffering' at work (Alvesson and Due Billing 1997, 1). Traditionally, the most striking internal division has been what Connell (2000) described as the gendered division of labour (148). The act of 'valuing the values' (Couldry 2010) of a workplace as masculine or feminine including division of labour becomes a question of how hegemonic and dominant values and attitudes are perceived and enacted. It is the 'interactional style' (Holmes 2006, 10) of the workers that constitutes the valuing processes. Therefore, acquiring different interactional styles within the educational workplace 'may be understood in gender-specific ways' and 'assigned gender attributes' (Haywood and Mac an Ghaill 2013, 84).

Notwithstanding the flourishing literature in the field of gender and masculinities, there have been a few attempts to consider gender differences among male primary teachers, with the notable exceptions of Haywood and Mac an Ghaill (2013) and Skelton (2001) in the UK, and Martino (2008) and King (1998) in Australia. In the Republic of Ireland, gender differences among primary teachers have been addressed in terms of patterns of gender variations between men and women (DES 2006, 2007; Drudy 2008, 2009; INTO 2004). This paper explores the distribution of a patriarchal dividend of power, control and authority among male Irish primary teachers. Whereas logical reasoning would appear to be gender neutral, the stories presented in this paper detail working relationships among men that 
not only include and exclude but also intimidate and exploit. In sum, this paper uses the concept of a contingent, hegemonic masculinity to map the uneven distribution of male power, authority and control across inter- and intra-gender segregation in contemporary primary schools.

\section{Gender diversities and recent statutory and policy contexts}

A number of recent statutory and policy developments have raised public consciousness about gender diversities. First, Ireland experienced a recent gender social, cultural and political reawakening. The Irish Marriage Equality Referendum in 2015 made statutory and policy history, with reverberations in the print, broadcast and popular media around the world, followed by apposite marriage equality legislation in other countries (Griffith 2013). Second, primary education has always been shaped by the strong cultural values placed on it in terms of the combined forces of state, church and society in the Republic of Ireland. Historically, primary schools have been embedded in local communities, or more accurately 'the parish', with a high social and cultural premium placed on teaching as a 'vocation' and on the teaching as 'a call' (Coolahan 2013) or what the novelist John McGahern referred to in 2006 as the second priesthood. Third, before the Republic of Ireland joined the European Union in 1973, it was possible for male applicants to gain places in Irish teacher education colleges with lower Leaving Certificate achievements than their female counterparts (Drudy 2009). Fourth, the main teacher education institutions in the Republic of Ireland have historically been denominational. A form of monopoly provision exists thorugh the school patronage regime. In plain terms, the State depends on private patrons and, in particular, the Catholic Church, and to a much lesser extent the Church of Ireland for school provision of denominational education. As John pointed out in his interview, 'It's not possible to be a teacher, to apply for training in Ireland, unless you already have a religion, preferably Christian'. Finally, a time series analysis presented in the report 'Sé/Sí' on behalf of the Department of Education and Science (DES) (O' Connor 2007) reveals that women have repeatedly outnumbered men among primary teachers in Ireland over the last 70 years. The report also illustrates that the proportion of female primary teachers increased steadily from $58 \%$ in 1930 to $83 \%$ in 2005 . While the total number of teachers at the primary level has more than doubled over those years, the actual number of male primary teachers has not varied greatly during the same period. The number of female entrants to teacher education colleges in counterpoint continues to rise, and clearly there is a cause for concern regarding the under-representation of men in primary schools and the challenges of attracting, recruiting and retaining male teachers.

\section{Participants' reasons for participating in a study of male teachers}

We begin by introducing the participants in this study whose words and worlds form the basis of this paper. A number of male primary teachers who agreed to participate in this study offered to write their own introduction or prologue. Where this was not possible, the introduction was written by the researcher based on the information supplied by the participant teacher. Each teacher also chose either to use a pseudonym or to keep his own name. The following details show the prior and anterior expectation 
of six participant teachers and how they viewed their impending participation in this research project.

John: I am interested in the role of men today. Roles are shared, roles are swapped more often ... Alas, it's the male who's made redundant and has no means. Power and position don't come from employment now or the ability to earn so therefore another set of values ... must be found. I am also curious about your definition 'masculinities', plural of masculinity.

David: Taking part in the research appealed to me because it gives me the opportunity to reflect on the issue of gender imbalance in teaching. It hasn't been spoken about before, that's very evident. Previously, the skewed gender distribution of teachers was a matter that I accepted rather than questioned.

Dan: I would be very happy to participate. It is applicable to me as I have taught in Senior Infants for the past two years, in two different schools, being the only male teacher on staff on each occasion.

Michael: I'd be interested in making a contribution to your study. I only have my own views and possibly some anecdotes around the issue of men (and boys) in education. I'm interested in this area and I think you're doing a very valuable job. I feel that further studies such as this are needed and should be encouraged.

Neil: I have been teaching for fifteen years in both rural and urban schools. Currently I am shared between two schools: one is an all-boys school. The other is a mixed school. In all cases it's overwhelmingly female, a predominantly female environment.

Matthew: I'd be very interested in taking part in your research about males in teaching. I've been teaching for eight years in a large school where there is pretty much 50:50 male:female ratio, which is fairly unusual. Just thought it might add another dimension to the research!

Taken individually and collectively, these capsule profiles suggest that at some deep level all lives are homogenous, which is to say parts of the greater whole and that there are continuities as well as discontinuities in the lived experiences of all teachers. In this way, universal and singular gender positionality are always linked and integrated and emergent patterns are potentially synchronous and nonsynchronous within and across social categories.

\section{Gendered positionality through a feminist and post-structuralist lens}

The theoretical orientations of feminism and post-structuralism and, more specifically, the work of the contemporary American philosopher and gender theorist, Butler (1999), whose work has influenced political philosophy, ethics and the fields of feminist, queer and literary theory also influenced the methodological choice, data collection and analysis for this research study. Building on Butler's (1999) influence, we take as our part of departure the notion that a feminist theoretical orientation disrupts traditional ways of knowing through its commitment to studying the 'lived experiences' of gender (Pillow and Mayo 2007, 161). Feminism places the personal being at the centre of one's enquiry. This positioning of the personal at the deep heart's core of the enquiry creates rich new meanings and highlights the conceptual markers of boundaries, identities and positionality. Furthermore, post-structuralism facilitates a constant engagement with 'the tensions and omissions' in a text 
(Jackson and Mazzei 2012, 5). This is what others have described as the importance of questioning and reading 'the hidden injuries of voice' (Couldry 2010) and 'the disappointments of voice' (Lather 2007).

A close post-structural reading of data induces a suspicion that 'something may be wrong with what we currently believe' (Jackson and Mazzei 2012, 23). As a result, post-structuralism holds true to the idea that no reading or writing of a life is ever complete or that a life is in a perpetual state of 'becoming', or what the French philosopher Michel Foucault believed to be the central and animating concern of becoming someone other than the person you were at the beginning. From this conviction emerged narrative accounts that 'are playful, open-ended, and incomplete' (Denzin 1989, 46; Van Maanen 2011). Taken together, a feminist perspective and a post-structuralist methodology can potentially facilitate the deconstruction of gendered social practices and support alternative understandings of power and subject formation. Deconstruction, in this sense, does not mean 'dismantling and replacing' or 'de-constructing and re-constructing' (Jackson and Mazzei 2012, 15). It is a tool that facilitates the possibilities for the stories of each teacher not as archetypes boxed into classrooms but as lives that go far beyond the pages of this manuscript.

\section{The long interview as a research method}

The method of inquiry utilised in this study is a tailored version of the long interview (Brinkmann and Kvale 2015; McCracken 1988; Spradley 1979). The research was designed to consist of three interconnected yet distinct phases of individual interviews. Phase One began on a personal level, exploring why primary teaching appealed to each participant, staffroom interactions and perceptions of care. Phase Two and Phase Three focused on the theme of gendered bodies: (1) teaching as a vocation, (2) society's view of the school and (3) the current labour market. The American anthropologist James P. Spradley's (1979) 'ethnographic interview' was used to guide informal interviews during Phase One. This ethnographic interview shares many features with a conversationbuilding format in which the researcher slowly and judiciously introduces a number of thematic and focusing questions. Phase One was not intended to reveal new or unusual experiences for male teachers. Yet, it was the familiar appeal of each story and the unfolding of each story that was significant in this early phase of the research project. An example of a familiar narrative is offered by David, who describes a time when he was asked to retrieve a ball that had fallen into a stream that flowed by the school.

I was asked to go in with Wellingtons and try and fish out the ball. I don't know why they thought I would be a good person to get the ball back?

In fact, the majority of the participants in the study expressed times when they have been given extra tasks to carry out by female colleagues. These tasks are always outside of their professional brief but which they are expected to carry out because they are men. Gender, in these cases, appears to make two jobs out of one (Hochschild 2012). Neil narrates gender inequality encountered at work.

There was a dead bird outside the school gate and I was asked to move it ... it could still be there for all I know because I didn't move it. I said "No, why are you asking me to move it?" ... I didn't hear of it anymore. 
Grant McCracken's (1988) 'long interview' was used to guide semi-structured interviews during Phase Two and Phase Three. The long interview is set within a generous time frame and allows participants to tell their own stories in their own terms. This technique enabled emerging themes to be explored in greater detail. In Phase Two and Phase Three, the focused was placed on how the assumptions presented by the participants are the result of their discursive constructions as male teachers. For example, Michael notes,

I know a primary school where the Principal who has just retired was always called Sir ... He was the only male [teacher] and the other seven [teachers] were female and they called him Sir and the children all called him Sir ... But why the word Sir? You know, it doesn't have anything but power connotations.

This discursive construction is further produced and reinforced by the long association between work and masculine self-identity. It also illustrates how history, language and philosophy have interacted and affected common-sense understandings of men and work. In an educational setting, terms that refer to male teachers such as 'Sir' or 'Master' may appear innocuous, but they are historical categories that permeate the way we think and talk about ourselves and others.

\section{Sample, contexts and settings}

Three rounds of interviews and note-taking in total allowed each phase of the research design to mutually inform one another, building confidence in the sampling (Rapley 2011, 285). Criterion-based sampling (Goetz and LeCompte 1984) used were as follows: (1) age: 6 participants were in the 20-35 year age bracket, 4 in the 35-50 year bracket, and 1 in the 50-65 year bracket; (2) school setting: 6 participants taught in a rural setting and 5 in an urban setting; Of the 11 participants, 9 worked in Catholic schools and 2 in multi-denominational Educate Together schools; (3) socio-economic school status: 3 participants worked in schools that implement the School Support Programme under the Delivering Equality of Opportunity in Schools (DEIS) Action Plan for Educational Inclusion (2005) - a plan focusing on prioritising the educational needs of children and young people from disadvantaged communities, 2 worked in primary urban DEIS Band 1 schools, 1 worked in a primary rural DEIS Band 1 school, and the remaining 6 worked in mainstream primary schools.

The participants graduated from three different initial teacher education programmes which were hosted in five different colleges of education. Ten participants attended teacher education colleges in Ireland; one participant attended a teacher education college in Wales in the United Kingdom. Eight participants were mainstream classroom teachers, two were Administrative Principals and one was a Learning Support Teacher. Of the eight mainstream classroom teachers, four were teachers in Junior Infants and Senior Infants and three taught in 4th class and 6th class. During the course of this research project, one teacher relocated to Abu Dhabi in the United Arab Emirates and one retired from teaching.

Overall, the participants in this research study formed a sample of maximum variety that supports information-rich data. Shared patterns and commonalities among participants were sought along with evidence of uniqueness. The sample size, although small, was selected on the basis of relevance to the research question. 


\section{Ethical considerations}

Ethical approval for this study was sought from, and granted by, the Research Ethics Committee (MIREC) at Mary Immaculate College, Ireland. Participants were advised of:

- the voluntary nature of participation;

- confidentiality and anonymity; and

- the purpose of the research.

\section{Findings about gendered positionality in the staff room}

The process of gendered positionality is difficult to discern because organisational logic seems on the surface to be gender neutral (Acker 1990, 142, cited in Gottfried 2013, 84). Furthermore, primary education has framed its engagements with masculinities in terms of a number of dichotomies such as sex/gender, man/woman and as biologically fixed and final, rendering it difficult to accept alternative versions of reality. Male staffroom practices and male power practices merged in the thematic data analysis.

\section{Nonsynchronous hegemonic masculinities}

Men's lives are shaped by the statuses they occupy. As teaching is considered a 'soft option' career for men (Connell 1985) and an essentially a feminine occupation rather than a masculine one, the masculinity of male teachers is continuously in doubt. Male teachers are constantly aware of others' attention about their maleness (cited in Skelton 2001, 127; Thornton 1997). Interview findings reveal distinct, though not absolute, hegemonic patterns in conversation-building among male teachers. Michael recounts a story that suggests male teachers are more willing to use coarse language in each other's company and appear to encourage each other to do so.

I was in a heavily male dominant staff one time, so there were twenty of us ... bad language as in swear words would have been ... all the time in the staffroom. Effing and blinding, the whole lot. The Principal was atrocious, in a nice way, you know? Fthis ... you know? He set the tone so the rest of us would have felt comfortable then about letting fly as well.

Haywood and Mac an Ghaill $(2013,14)$ state that men occupy a hegemonic masculinity 'or assert a position of superiority' by 'winning the consent of other males ... in order to secure their (hegemonic) legitimacy'. Furthermore, Bradley $(2013,157)$ claims, even in situations of warmth and companionship, 'embodied masculinity remains on display'. Neil supports Michael's depiction of a different tone in staffroom conversations, describing it as accepted, when male teachers are in the majority.

... you would be less maybe concerned and you could go further with the banter ... where as you would be slightly more cautious when the genders cross because men have a different view of what you can slag people off on or ... have a bit of banter about them than maybe what women have. Women when together might understand, have a different view point on what is, kind of, fun or in that sense ... There's just a different view point really more than anything else. 
The verbal exchanges in these stories bring into question hegemonic masculinities in schools. According to Connell (1996), hegemonic masculinities sustain a number of relationships with men that operate through processes of subordination, complicity and marginalisation (Haywood and Mac an Ghaill 2013, 105). Superiority and exclusionary practices among male colleagues are evident in the following stories of Tim and Matthew who detail an exclusionary form of interaction among male colleagues. Tim states:

I find it much easier to talk to the female staff personally, that's my own personal thing whereas I see that all the males would talk to each other bar myself and another fella ... Nothing against the other male teachers, it's just that they do give off the vibe of machoism and big bravado and they wouldn't talk about every single interest in the world. They would have their one specific topic and if you are not part of that loop... they won't talk to you.

Matthew's depiction of segregated staffroom seating plans hints at hegemonic isolation practices among male teachers. It also suggests practices of isolation among male teachers because of Matthew's regular interaction with female colleagues.

Now there is the whole ... the staffroom thing with all the lads in one corner and then, you know, I would sit with a group of girls that all started together, you know? We are actually pretty close friends ... but all the lads sit together and we would have three new male members of staff and they sit over with the lads.

Schools are organisations that establish what Connell $(1987,120,2002,53)$ terms a 'gender regime'. These regimes work to maintain existing gender norms within organisations. Tim understands male teachers' unwillingness to broaden the topic of conversation as a fear of portraying too much femininity, 'You can't give off any viable femininity in your personality or your character or else you would have to assert your masculinity'. Similarly, Bradley $(2013,157)$ notes that where friendship groups are heterosexual, wariness remains about possible misinterpretations of emotionality. Through the manipulation of gendered power relationships at the micro-political level, the traditional model of male dominance is turned on its head. Tim further details heterosexual friendships in the staff room:

I can see it in them, that they would have to portray I am the man. I am a man here in this job. I do what men do ... I will talk like a man, I will walk like a man, I will teach like a man, and I don't get that. We are all teaching the very same way.

It could be deduced that the male teachers in these situations were working within the structures of a 'gender regime' (Connell 1987, 1120). This pattern suggests that male teachers are able to change the structure of working relationships by positioning other men as subordinate and marginalised.

\section{Male subordination and marginalisation practices}

Gender relations within a feminine environment are central to understanding masculinities in primary schools. Yet, differences are not solely due to gender but to different power positions at different times (Kimmel 2013, 11). These relationships are 
constructed through practices that exclude and include, that intimidate and exploit (Connell 1995, 37). The following stories illustrate that men are able to locate themselves in powerful positions over other men and women by way of subordination and marginalised relationships. Matthew recalls a time that the Principal of his school marginalised him as well as his female colleagues.

There was a golf classic on a Friday afternoon for a sports club, I think it was the GAA club or something ... the Principal took about six or seven of the lads to play golf at about half twelve during the day, out of school when they were supposed to be working and got other people [female teachers] to fill in and look after their classes ... he didn't ask any of the female teachers if they wanted to play.

Connell $(1993,62)$ proposes that the school should be viewed not only for its teaching but also its atmosphere as a workplace, '... we also need to think about the character of the school as a workplace'. As in all workplaces, there is a structure of authority of control. In schools, an institutional expression of the power is in school administration (Kimmel 2001, 38). Connell (1993, 62) notes the 'obvious features' of a school's system of authority of control as 'school administrative apparatus (principal ...)' and 'financial arrangements (links to the school board, and DES)'. Less obvious features are ' ... the informal balance of power among the personalities and factions among a school's staff' (62). For instance, relations of alliance, domination and subordination were evident in Tim's story:

I watch the GAA and that's about it but when GAA season is over, I have nothing to talk to the male staff about ... Not that they won't talk to you, it's just that like, you would be sitting there in the middle of the conversation going 'I have nothing to say here. I have no interest in this whatsoever' ... I don't know how to approach this conversation so I am glad a female member of staff is sitting beside me...

Connell $(1993,62)$ refers to the political order of a school as an institution, which is the 'set of arrangements and divisions that define who has authority or power, and over what'. The political order of schools has changed in the past decade as teachers develop and contest new work identities in response to contradictory workplace demands. Matthew's following story illustrates marginalisation through the use of technology.

On another occasion actually he sent a text around. He was looking for people to play golf with and he sent a text around saying 'Men of [X]-town'. It was the only time he sent me a text. He wouldn't consider me one of the men. I was one of the annoyances in his side to be honest with you ... he wouldn't text the girls.

Marginalisation is also evident in Matthew's story detailing his lack of involvement in staff races during the school's annual sports days.

I am useless at sport. I do not get involved in Sports Days ever. I bring my class over and we take part and all the rest but in terms of staff races and things like that I don't take part. It used to be commented on by our Principal, he was like 'Oh, you are not taking part there, Matthew?'

Connell (1987, 84-85) notes that images of masculinities in Western countries 'are constructed and promoted most systematically through competitive sport'. This may 
suggest why the Principal of Matthew's school is surprised that he is not partaking in the teacher race and may partly offer a reason why Matthew does not wish to engage in the race.

\section{Discussion of gendered positioning among Irish male teachers}

A key aspect of male teachers' identity is the performance of a public masculinity. Masculinities are produced through the work that bodies do. As a result, male teachers adopt different styles in the workplace. Just as masculinities are aligned in relation to setting practices, such as the staffroom or the classroom, schools themselves are sites where 'male dominance is regulated, normalized and legitimized' (Skelton 1996, 23). Many kinds of practice produce knowledge (Connell 1995, 37). One practice termed hegemony or the organisation of masculinities into hierarchical order was a regular pattern in the stories told by participants. Hegemonic masculinities refer to modes of masculinities that claim the 'highest status and exercise the greatest influence and authority' (Skelton 1996, 50). That is to say, they are both dominant and dominating. Hegemonic masculinity is considered to be a 'selective range of categories culturally associated with the masculine' (Collier 1998, 19). These categories include qualities such as aggression, 'macho', pride, competitiveness and duty. The emotional traits associated with hegemonic masculinity are aggression, dispassion and ruthlessness (Gottfried 2013, 83). Similarly, hegemonic masculinity, which signifies 'a position of cultural authority and leadership' (Connell 1996, 209), privileges the expression of 'care-free' emotional displays 'that appear natural and rational' (Gottfried 2013, 889). However, the concept of hegemonic masculinity is limited. First, the characteristics associated with hegemonic masculinity could apply to women as well as men. Second, the concept is presented in a contradictory manner. It is presented as a correlative of masculine behaviour. These traits associated with hegemonic masculinity are seen to signify 'the masculine' in many circumstances. Yet, these very markers of masculinity are also considered the cause of men's behaviour.

\section{The politics of power, control and privilege among teachers}

In primary schools, the concept of authority has been associated with male teachers and with hegemony. This can be seen through various institutional practices: male teachers are more likely to have responsibility for senior classes, occupy decision-making roles such as Principal, Assistant Principal and generally maintain discipline throughout the school. Connell (1995) maintains that to recognise diversity within a setting is not enough. We must also 'recognize the relations between the different kinds of masculinity' (Connell 1995, 37). In order to achieve this, we must consider the gender regime of the school. In other words, we must identify the pattern of practices that construct various kinds of masculinities among male and female staff, which orders them in terms of 'prestige and power, and constructs a sexual division of labour within the institution' (Kessler et al. 1985, 45, cited in Skelton 1996, 23). Patterns of masculinities appear most evident through authority patterns: authority and surveillance - appropriate gender behaviours; authority of control - discipline and authority and alliance - the marginalisation of others both male and female. 'These authority patterns carry with them particular implications for modes of masculinity and femininity' (Skelton 1996, 29). Authority and discipline are often synonymous with the role of a male 
primary teacher. When authority is considered in relation to male teachers and their working relationships with other male teachers, it suggests exclusionary practices that are relevant to a materialist reading of data.

Connell $(1995,71)$ considers gender as a social practice that 'constantly refers to bodies and what bodies do' but is not a 'social practice reduced to the body'. The starting point of this definition is that social practice interacts with historical situations and not the result of individual actions (Skelton 1996, 49). Connell $(1995,72)$ terms this as gender projects or the 'processes of configuring practice through time, which transform their starting-point in gender structures ...' Just as Butler (1999, xvii) considers gender to be an internally complex structure, Connell (1995) puts forward a three-fold model of the structure of gender relations: power, production and emotional attachment. This model provides a means of considering masculinities and femininities in relation to one another rather than looking at gender differences. It does not, however, illustrate how social practices emerge through intra-actional dynamics.

Representations of men and women have different meanings in different contexts. For example, in accounts of male violence, men appear to have 'little problem expressing their emotions' (Collier 1998, 28). This suggests a strong link between the male body and characteristics which are deemed masculine. To state as much is not to make an essentialist claim (28) but to suggest the ways that history, culture and psychology have intertwined to create accepted notions of masculinities. It also suggests that teachers' awareness of other male teachers' discipline styles, which are informed by notions of masculinities, create 'good' teachers. As Matthew concludes from his story, the female teacher in his company felt happy that he took charge of the situation in a masculine manner through the use of his body, his powerful voice and authoritative presence in this instance.

... the kids as well would respond to my voice quicker than they would to the girls' voices during assembly or things because I'm louder, you know my voice is deeper, it's different, you know. They are not used to hearing that voice.

Male teachers adopt different styles in the workplace. Through their compliance with it, they are in fact working with hegemonic masculinities rather than against them. The themes of 'machismo' and creating bonds with male pupils are also evident in the stories recounted by many of the participants in this study. 'When teachers (male or female) adopt more authoritarian types of discipline with male pupils ... they are helping to create the 'macho' modes of masculinity ...' (Skelton 1996, 30). Writers argue that 'a violent discipline system, particularly one locked into an educational system of academic success or failure, invites competition in "machismo" ... between the boys and male teachers' (Skelton 1996, 30).

\section{Bodily boundaries as variables of performative gender processes}

The body is not an answer to all our questions (Colebrook 2004). It is not 'something that we would find at the end of knowledge and questioning' but must be considered a 'power to provoke the ways in which we think' (Colebrook 2004, 219). There is an obvious physical body understanding by the way our social conditioning teaches us to see a person. Traditional representation of the body is purely in biological and natural form (Bordo 1993, 33). Nevertheless, 'why should our bodies end at the 
skin?' (Haraway 1991). The body has always been different to the mind and as such has always been considered passive and inactive. As a result, differences within the generic description of 'man' were lost. Consequently, we know very little about the differences among men. Socio-political perspectives on boyhood have been very useful in highlighting the importance of culture and historical context in how boys learn to define and negotiate their masculinities (Martino 2008, 46). More clearly, it indicates the direction this conversation should take. This new direction reinstates the material into the discursive, 'an ontological re-orientation', that emphasises the inseparable nature of language and the material (Jackson and Mazzei 2012, 112). Knowledge has a specific relationship with this new direction that includes moving the boundaries of what can be known to include larger material configurations of the world.

Power is not only understood through the logic of domination but as a performative process that encompasses agency, causality, dynamics and topologies. An exploration of masculinities in this format allows for a broader framework that includes human and non-human intra-actions, creating possibilities for other forms of power to constitute the body. Agency, when understood as 'doing' and 'being', was evident in the intra-activity of male teachers with their environments: conversations with other male colleagues, enactments of public masculinities and negotiating the school building. Dynamics are illustrated through the shifting boundaries between public and private in relation to work and the performance of masculinities. Questions of abstract bodies such as neo-liberalism, neoconservatism, meeting economic needs and their intra-action with education are topological concerns. Body matters have a 'tenuous link' to gender domination in feminist theories (Gottfried 2013, 85). Feminism shares with post-structuralism not only 'the sense of a crisis of the Logos' but the need for renewed conceptual creativity of the present (Braidotti 2002, 11). Extending the body beyond discourse to consider the material encourages us to think not what a body is but what a body can do. "This means that "embodied" accounts illuminate and transform our knowledge of ourselves and of the world' (Braidotti 2002, 12). Research on the body provides '... a fresh look at the social construction of femininity and masculinity ... and a new focus on embodiment' (Gottfried 2013, 86).

\section{Conclusion}

R.W. Connell's theory of hegemonic masculinities (1982) has led us on a journey that has not yet come to a conclusion. While a great deal of conceptual confusion has surrounded the concept of masculinities, particularly evident in accounts of masculinity in pop psychology (Gray 1992) and in the mythopoetic men's movement (Bly 1990), the underlying disorder has been conceptually useful. Diverse research on masculinities in various social and cultural settings has emerged precisely because the basic hegemonic masculinities concept is not unified or stable. Two key findings are suggested in this paper. The first finding focuses on the development of hegemonic masculinities in terms of divisions among men, especially the exclusion and subordination of some men by other men. The teaching styles some male teachers choose to adopt reinforce existing stereotypes, with hardness and toughness, rather than challenging them. While challenging the normative ascriptions of masculine behaviours, some of the teachers in this study also took up a heroic sense of masculinity, whereby they pioneered the care of young children (Haywood and Mac an Ghaill 2013, 108). The 
second finding focuses on nonsynchronous performative masculinities, which capture the professional institutional specificities of this cultural space. The dynamism of performative masculinities provides a feel of late modern emerging genders/sexualities that are being actively produced within primary schools as work environments. Running concurrently to this cultural backdrop are historical sex/gendered structures emanating from a range of 'big' institutions: state, church and union, at a time of global change that is underpinned by subtle epistemological understandings of complex subjectivities.

This paper recommends placing a growing appreciation on the need for research that advances a more equal world. It recommends exploring ' ... the links between knowledge and power' (Lather 1991, 19) and challenging accepted forms of knowledge or 'the naturalness of social arrangements' (Lather 1991, 63). The research design of this study created conditions in which the teachers, as participants, were involved in discussions that were more than 'merely research answers'. They responded as highly reflexive participants, as they were given the space to think through masculinity identity work in the work place. This paper is written in an accessible manner and will appeal to both gender experts and those with a broader interest in educational research.

\section{Notes on contributors}

Suzanne O'Keeffe completed a PhD degree at Mary Immaculate College, Limerick, in 2016. Suzanne's teaching and research interests include care, democratic research designs and masculinities.

Jim Deegan is Professor and Head of Graduate School, Mary Immaculate College, Limerick, and a former Associate Professor of Teacher Education, University of Georgia, Athens, GA, USA. His publications focus on the sociology of children's peer cultures, teaching and teacher education, autobiographical and narrative inquiry, and teachers, children and families in social regeneration communities.

\section{ORCID}

Suzanne O'Keeffe (i) http://orcid.org/0000-0002-4344-2488

\section{References}

Acker, J. 1990. "Hierarchies, Jobs, Bodies: A Theory of Gendered Organizations." Gender \& Society 4: 139-158.

Alvesson, M., and Y. Due Billing, 1997. Understanding Gender and Organisations. Thousand Oaks, CA: SAGE Publications.

Apple, M. W. 2013. Can Education Change Society? New York: Routledge.

Bly, R. 1990. Iron John. A Book About Men. Dorset: Element Books Limited.

Bordo, S. 1993. Unbearable Weight. Feminism, Western Culture, and the Body. Los Angeles: University of California Press.

Bradley, H. 2013. Gender. 2nd ed. Cambridge, UK: Polity Press.

Braidotti, R. 2002. Metamorphoses. Towards A Materialist Theory of Becoming. Oxford, UK: Polity Press.

Brinkmann, S., and S. Kvale. 2015. Interviews: Learning the Craft of Qualitative Research Interviewing. 3rd ed. Thousand Oaks, CA: SAGE Publications.

Butler, J. 1999. Gender Trouble: Feminism and the Subversion of Identity. New York: Routledge. 
Colebrook, C. 2004. The Sense of Space: On the Specificity of Affect in Deleuze and Guattari. Baltimore, MD: The Johns Hopkins University Press.

Collier, R. 1998. Masculinities, Crime and Criminology: Men, Heterosexuality and the Criminal (ised) Other. London: SAGE Publications.

Connell, R. W. 1985. Teachers' Work. London: Allen and Unwin.

Connell, R. W. 1987. Gender and Power. Cambridge, UK: Polity.

Connell, R. W. 1993. Schools and Social Justice. Philadelphia, PA: Temple University Press.

Connell, R. W. 1995. Masculinities. Sydney: Allen and Unwin.

Connell, R. W. 1996. "Teaching the Boys: New Research on Masculinity, and Gender Strategies for Schools." Teacher College Record 98 (2): 206-235.

Connell, R. W. 2000. The Men and the Boys. Sydney: University of California Press.

Connell, R. W. 2002. Gender. Cambridge, UK and Malden, MA: Polity Press and Blackwell Publishers.

Coolahan, J. 2013. "Towards an Era for Teacher Education and the Engagement of the Teaching Profession." Irish Teachers' Journal 1 (1): 9-26.

Coolahan, J., C. Hussey, and F. Kilfeather. 2012. The Forum on Patronage and Pluralism in the Primary Sector: Report of the Forum's Advisory Group. Dublin: Department of Education and Skills.

Couldry, N. 2010. Why Voice Matters: Culture and Politics After Neoliberalism. London: SAGE.

Denzin, N. K. 1989. Interpretive Biography: Qualitative Research Methods. 17 vols. London: SAGE Publications.

Department of Education and Science. 2006. Males into Primary Teaching. Dublin: Department of Education and Skills.

Department of Education and Science. 2007. Sé sí: Gender in Irish Education. Dublin: Stationery Office.

Department of Education and Skills. 2016. "Education at a Glance 2016. OECD Indictors. A Country Profile for Ireland. Statistics Section.” September. https://www.education.ie/en/ Publications/Statistics/International-Statistical-Reports/Education-at-a-Glance-OECDIndicators-2016-Briefing-Note.pdf.

Drudy, S. 2008. "Gender Balance/ Gender Bias: The Teaching Profession and the Impact of Feminisation." Gender and Education 20 (4): 309-323.

Drudy, S., ed. 2009. Education in Ireland: Challenge and Change. Dublin, OH: Gill \& Macmillan.

Eurydice. 2015. "Teachers' and School Heads' Salaries and Allowances in Europe 2014/15. Eurydice - Facts and Figures." http://eacea.ec.europa.eu/education/eurydice/documents/ facts_and_figures/188EN.pdf.

Goetz, J., and M. LeCompte. 1984. Ethnography and Qualitative Design in Educational Research. New York: Academic Press.

Gottfried, H. 2013. Gender, Work, and Economy: Unpacking the Global Economy. Cambridge, UK: Polity.

Gray, J. 1992. Men Are from Mars, Women Are from Venus. New York: HarperCollins.

Griffith, M. 2013. "Love, Commitment, Family, Equality - The Case for Marriage Equality in Ireland. Marriage Equality's Submission to the Constitutional Convention." http://www. marriagequality.ie/download/pdf/final_me_constitutional_convention_submission.pdf.

Haraway, D. 1991. Simians, Cyborgs, and Women: The Reinvention of Nature. New York: Routledge.

Hargreaves, A. 2001. "The Emotional Geographies of Teachers' Relations with Their Colleagues." International Journal of Educational Research 35: 503-527.

Hargreaves, A. 2010. "Presentism, Individualism, and Conservatism: The Legacy of Dan Lortie's Schoolteacher: A Sociological Study." Curriculum Study 40 (1): 143-154.

Haywood, C., and M. Mac an Ghaill. 2013. Education and Masculinities: Social, Cultural and Global Transformations. New York: Routledge.

Hochschild, A. R. 2012. The Managed Heart. Commercialization of Human Feeling. Berkeley, CA: University of California Press.

Holmes, J. 2006. Gendered Talk at Work: Constructing Gender Identity Through Workplace Discourse. Oxford: Blackwell Publishing. 
Holohan, C., and T. Tracy. 2014. Masculinity and Irish Popular Culture: Tiger's Tales. London: Palgrave Macmillan.

INTO (Irish National Teachers Organisation). 2004. Gender Imbalance in Primary Teaching A Discussion Document. The Demise of the Male Primary Teacher? Dublin: INTO Publications.

INTO (Irish National Teachers' Organisation). 2016a. "Stand Up for Primary Education. Budget/ General Election 2016." https://www.into.ie/ROI/StandupforPrimaryEducation/ StandUpPrimaryEd.pdf.

INTO (Irish National Teachers' Organisation). 2016b. "Shortage of Substitute Teachers." http:// www.into.ie/ROI/NewsEvents/LatestNews/NewsArchive/NewsArchive2016/December2016/ Title,40435,en.php.

IPPN (Irish Primary Principals' Network). 2006. "Investing in School Leadership. A Review and Analysis of the Factors Contributing to the Recruitment \& Retention Crisis in Primary School Principalship to be Addressed by the Public Service Benchmarking Body 2006/7." http://www.ippn.ie/index.php?option=com_mtree\&task=att_download\&link_id= $4 \& \mathrm{cf} \_$id $=24$.

Jackson, A. Y., and L. A. Mazzei. 2012. Thinking with Theory in Qualitative Research: Viewing Data Across Multiple Perspectives. London: Routledge.

Kessler, S., D. J. Ashenden, R. W. Connell, and G. W. Dowsett. 1985. "Gender Relations in Secondary Schooling." Sociology of Education 58: 34-48.

Kimmel, M. 2001. The Gendered Society and the Gendered Society Reader. Oxford: Oxford University Press.

Kimmel, M. 2013. The Gendered Society. 5th ed. New York: Oxford University Press.

King, J. R. 1998. Uncommon Caring: Learning from Men Who Teach Young Children. Early Childhood Education Series. New York: Teachers College Press.

Lather, P. 1991. Getting Smart. Feminist Research and Pedagogy With / In the Postmodern. New York: Routledge.

Lather, P. 2007. "Validity, Qualitative." The Blackwell Encyclopedia of Sociology, edited by George Ritzer, 5161-5165. Oxford: Blackwell. 300 word version published in Concise Blackwell Encyclopedia of Sociology, 2008.

Lupton, D. 1998. The Emotional Self: A Sociocultural Exploration. London: SAGE Publications.

Martino, W. J. 2008. "Male Teachers as Role Models: Addressing Issues of Masculinity, Pedagogy and the Re-Masculinization of Schooling." Curriculum Inquiry, 38(2). doi:10. 1111/j.1467-873X.2007.00405.x.

McCracken, G. 1988. The Long Interview: Qualitative Research Methods Series 13. London: SAGE Publications.

Mowbray, J. 1997. "Where I Stand: Irish a Mix of Ego, Stubbornness, Great Charm and Wit." Las Vegas Sun, March 17.

O' Connor, M. 2007. Sé-Sí - Gender in Irish Education, on Behalf of the Department of Education and Science. Dublin, OH: Government Publications Sales Office.

Pillow, W. S., and C. Mayo. 2007. "Toward Understandings of Feminist Ethnography." In Handbook of Feminist Research. Theory and Practice, edited by S. N. Hesse-Biber, 155171. London: SAGE Publications.

Popkewitz, T., and S. Lindblad. 2000. "Educational Governance and Social Inclusion: Some Conceptual Difficulties and Problematics in Policy and Research." Discourse: Studies in the Cultural Politics of Education 21: 5-44.

Rapley, T. 2011. "Some Pragmatics of Data Analysis." In Qualitative Research: Issues of Theory, Method and Practice, 3rd ed., edited by D. Silverman., 273-290. London: SAGE Publications.

Skelton, C. 2001. Schooling the Boys: Masculinities and Primary Education. Buckingham: Open University Press.

Skelton, C. 1996. "Learning to be Tough: The Fostering of Maleness in One Primary School." Gender and Education 8: 185-97.

Skelton, C., and B. Francis. 2009. Feminism and the Schooling Scandal. London: Routledge.

Spradley, J. P. 1979. The Ethnographic Interview. New York: Holt, Rinehart and Winston. 
Thornton, M. 1997. "Gender Issues in the Recruitment, Training and Career Prospects of Early Years and Primary School Teachers." Paper presented to the British Educational Research Association Conference, University of York, September 11-14.

Tuohy, D. 2013. Denominational Education and Politics: Ireland in a European Context. Dublin, $\mathrm{OH}$ : Veritas.

Van Maanen, J. 2011. Tales of the Field: On Writing Ethnography. 2nd ed. Chicago Guides to Writing, Editing, and Publishing. Chicago, IL: The Chicago University Press. 